UJBM, Vol. 7, No. 2, July - December 2008, pp 13-27

ISSN 0975-3311 | https://doi.org/10.12725/ujbm.13.2

\title{
FAIRNESS CREAM: A STUDY ON BRAND PREFERENCE OF CONSUMERS IN GOBICHETTIPALAYAM TOWN
}

\author{
N. Sakthivel*
}

\section{Introduction}

Fairness cream market is growing segment of the personal care product industry. The urban population in India is being increasingly influenced by spurt of fairness cream entry into the market. Recently 30 brands of fairness creams are found in all urban places, fair and lovely is the highest penetrated brand. In this industry, there is a high entry barrier due to the strong brand preference of the existing players. Companies are canalizing greater part of their sources towards promotion of new products. Fairness cream companies offering a large range of brands typically promote one or two products at any given time, Soaps and talcum powders. Godrej introduced fair glow soap as thousand year's item. Hindustan Lever introduced lux, sunscreen soaps in the year 2001.

* Lecturer In Commerece, Gobi Arts \& Science College, Gobichettipalayam, Erode, Tamilnadu - 638453. E-mail Id \& Phone Numbers: Sakthivel_Gasc@Rediffmail.com, 09786677899 \& 04285-310090. 
All fairness cream companies conduct market expansion programmes in rural areas to cover more segments and to educate the people more about the product. Hindustan lever limited introducing the number of fairness creams in to the market. It has introduced sachet selling system and cover economically weaker section. They can produce competition in the fairness cream market. Women's have been using fairness creams for thousands of years. Fairness cream is one of the popular products used by women. It has been traditionally used for its fragrance and feeling of fairness. There are number of companies marketing their fairness cream under different brand names. The major ingredients are more or less the same. However, the consumer satisfaction of a product plays an important role in determining the product success or failure. Hence, an attempt is made to study the brand preference of fairness cream consumers in Gobichettipalayam town.

\section{Scope of the Study}

This study is confined to Gobichettipalayam town, Erode District, Tamilnadu. This study deals with the Brand Preference of Fairness Cream Consumers and various problems faced by the fairness cream consumers. This study considers five brands of fairness cream such fair ever, fair \& lovely, fair one, garnier and vicco turmeric.

\section{Objectives of the Study}

The objectives of the study are:

- To analyze the factors influencing the brand preference of fairness cream consumers

- To study the problems faced by the fairness cream consumers

\section{Hypothesis of the Study}

Ho: There is no Significant Relationship between Personal-Economic Factors (age, gender, education, marital status, type of family, monthly income, monthly expenditure and monthly expenditure for fairness cream) and brand preference of fairness cream consumers. 


\section{Sampling Design and Data Collection}

For the present study, 200 fairness cream consumers are selected as sample respondents by. adopting convenience sampling technique. This study is based on primary data and required primary data are collected from sample respondents by using well-structured interview schedule.

\section{Data Analysis}

For analyzing the primary data, simple ranking analysis, chi-square analysis and percentage analysis are applied and interpretations are made. Chisquare analysis is applied at $5 \%$ level of significance.

\section{Analysis and Interpretations}

\section{Brand Preference of Fairness Cream Consumers}

As there are number of brands of Fairness creams products available in the market, the choice of consumers is very difficult. Before purchasing a particular brand, consumers consider several factors such as quality, price, availability etc. They would purchase the brand, which satisfies them in all aspects. In this study, an attempt is made to analyze the brand preference of fairness cream consumers. For analyzing this, five brands of fairness cream are taken into account such as fair ever, fair \& lovely, fair one, garnier and vicco turmeric. The table 1 shows the brand preference of fairness cream consumers.

Table 1: Brand Preference of Fairness Cream Consumers

\begin{tabular}{|l|c|c|}
\hline \multicolumn{1}{|c|}{ Brands } & No. of Respondents & Percentage \\
\hline Fair Ever & 34 & 17.0 \\
Fair \& Lovely & 73 & 36.5 \\
Fair One & 21 & 10.5 \\
Garnier & 50 & 25.0 \\
Vicco turmeric & 22 & 11.0 \\
\hline Total & 200 & 100 \\
\hline
\end{tabular}

Source: Primary Data 
The table. 1 shows that out of 200 sample respondents, the majority (73) of them prefer 'Fair \& Lovely. Among 200 sample respondents, $17 \%$ of them prefer 'Fair Ever', $10.5 \%$ of them prefer 'Fair One', $25 \%$ of them prefer 'Garnier' and $11 \%$ of them prefer 'Vicco Turmeric'. Hence, it is concluded that the majority of the consumers prefer 'Fair \& Lovely' brand of fairness cream.

\section{Preference of Quantity of Fairness Cream}

Consumers may prefer their quantity of fairness cream by considering number of family members and frequency of purchase. Hence, it is decided to analyze the preference of quantity by the consumers of fairness creams. The table 2 reveals the brand preference of quantity of fairness cream by the consumers.

Table 2: Preference of Quantity by Sample Respondents

\begin{tabular}{|l|c|c|}
\hline \multicolumn{1}{|c|}{ Quantity Preferred } & No. of Respondents & Percentage \\
\hline Up to $50 \mathrm{gms}$ & 130 & 65 \\
Above $50 \mathrm{gms}$ & 70 & 35 \\
\hline Total & 200 & 100 \\
\hline
\end{tabular}

Source: Primary Data

The table 2 shows that out of 200 sample respondents, $65 \%$ of them preferred 'up to 50 grams' and $35 \%$ of them preferred 'above 50 grams'. Hence, it is concluded the majority (130) of the sample respondents preferred 'up to 50 grams'.

\section{Sources of Information}

The source through which the consumers have received the information about a particular brand plays an important role in modern marketing. In this regard, advertisements play a vital role to describe about a particular product. Now a days, Advertising through various media has become popular. Hence, it is decided to analyze the source through which the consumers got the information about the Fairness creams. The table 3 reveals the sources of information through which consumers have received the information about a particular brand of fairness cream. 
Table 3: Sources of Information

\begin{tabular}{|l|c|c|}
\hline \multicolumn{1}{|c|}{ Sources } & No. of Respondents & Percentage \\
\hline Friends & 42 & 21 \\
Relatives & 22 & 11 \\
Doctor's Advice & 54 & 27 \\
Advertisements & 82 & 41 \\
\hline Total & 200 & 100 \\
\hline
\end{tabular}

Source: Primary Data

The table 3 shows that out of 200 sample respondents, $21 \%$ of them got information about a particular brand of fairness cream through 'friends', $11 \%$ of them got information through 'relatives', $27 \%$ of them got information through 'doctor's advice' and $41 \%$ of them got information through 'advertisements'. Hence, it is concluded that the majority (82) of the sample respondents got information about a particular brand of fairness cream through 'advertisements'.

\section{Place of Purchase}

Easy availability of fairness cream products to the consumers is an important factor to be considered. Where can the consumers get their fairness cream is being considered, because of non-availability of fairness creams leads to preference of other alternatives by the consumers. Hence, it is decided to analyze the place of purchase by fairness cream consumers. The table 4 reveals the place of purchase by fairness cream consumers.

Table 4: Place of Purchase

\begin{tabular}{|l|c|c|}
\hline \multicolumn{1}{|c|}{ Place of Purchase } & No. of Respondents & Percentage \\
\hline Departmental Stores & 46 & 23 \\
Retail Shops & 38 & 19 \\
Medical Shops & 100 & 50 \\
Ayurvedic Shops & 16 & 8 \\
\hline Total & 200 & 100 \\
\hline
\end{tabular}

Source: Primary Data 
The table 4 shows that out of 200 sample respondents, $23 \%$ of them purchased their brand of fairness cream from 'departmental stores', $19 \%$ of them purchased their brand of fairness cream from 'retail shops', $50 \%$ of them purchased their brand of fairness cream from 'medical shops' and $8 \%$ of them purchased their brand of fairness cream from 'ayurvedic shops'. Hence, it is concluded that the majority (100) of sample respondents purchased their brand of fairness cream from 'medical shops'.

\section{Factors Influencing the Brand Preference of Fairness Cream Consumers}

Normally, consumers consider various factors before making purchase of any product. For making effective purchase, consumers consider the factors like price, quality, quantity, brand image etc. These factors influence the consumers to choose the particular brand. By considering this, an attempt is taken to analyze the factors influencing the fairness cream consumers to select their brand of fairness cream. For analyzing the factors influencing the brand preference of fairness cream consumers, ten factors (Price, Quality, Quantity, Package, Brand reputation, availability, advertisement, odour, freshness and discount offer) are considered. For identifying the most significant factor influencing the brand preference of fairness cream consumers among these factors, simple ranking technique has been applied. The table 5 reveals the ranking analysis of factors influencing the brand preference of fairness cream consumers.

Table 5: Factors Influencing the Brand Preference of Fairness Cream Consumers; Ranking Analysis

\begin{tabular}{|l|c|c|c|}
\hline \multicolumn{1}{|c|}{ Factors } & Total Score & Mean Score & Rank \\
\hline Price & 1286 & 6.43 & 2 \\
Quality & 1656 & 8.28 & 1 \\
Quantity & 1146 & 5.73 & 4 \\
Package & 1048 & 5.24 & 6 \\
Discount Offer & 762 & 3.81 & 10 \\
Freshness & 1224 & 6.12 & 3 \\
Reputation & 894 & 4.47 & 8 \\
Availability & 1088 & 5.44 & 5 \\
Advertisement & 1012 & 5.06 & 7 \\
Odour & 884 & 4.42 & 9 \\
\hline
\end{tabular}

Source: Primary Data 
The table 5 shows that among the ten factors considered, quality is ranked as first factor with total score of 1656. Price (1286), freshness (1224), quantity (1 146) and availability (1088) are ranked as second, third, fourth and fifth factors respectively and other factors followed them. Hence, it is concluded that the quality is the most significant factor, which influences the brand preference of fairness cream consumers.

\section{Personal - Economic Factors Influencing the Brand Preference of Fairness Cream Consumers}

Age wise distribution of sample respondents

Table 6: Age of Sample Respondents

\begin{tabular}{|l|c|c|}
\hline \multicolumn{1}{|c|}{ Age group } & No. of Respondents & Percentage \\
\hline Young (up to 40 Years) & 116 & 58 \\
Old (above 40 Years) & 84 & 42 \\
\hline Total & 200 & 100 \\
\hline
\end{tabular}

Source: Primary Data

From the table 6, it is found that out of 200 sample respondents, the majority (116) of the sample respondents belong to the Young age group and $42 \%$ of the sample respondents belong to the Old age group. Hence, it is concluded that the majority of the sample respondents belong to the Young age group.

\section{Gender wise distribution of sample respondents}

The table. 7 shows the distribution of the sample respondents on the basis of their gender.

Table 7: Gender of Sample Respondents

\begin{tabular}{|l|c|c|}
\hline \multicolumn{1}{|c|}{ Gender } & No. of Respondents & Percentage \\
\hline Male & 36 & 18 \\
Female & 164 & 82 \\
\hline Total & 200 & 100 \\
\hline
\end{tabular}

Source: Primary Data 
From the table 7, it is found that out of 200 sample respondents, the majority (164) of the sample respondents are female and only $18 \%$ of the sample respondents are male. Hence, it is concluded that the majority of the sample respondents are female.

\section{Education wise distribution of sample respondents}

The table 8 shows the distribution of sample respondents on the basis of their education. For analyzing this, sample respondents are grouped into three groups viz., School level, College level and No formal education.

Table 8: Education of Sample Respondents

\begin{tabular}{|l|c|c|}
\hline \multicolumn{1}{|c|}{ Education } & No. of Respondents & Percentage \\
\hline School Level & 36 & 18 \\
College Level & 144 & 72 \\
No Formal Education & 20 & 10 \\
\hline Total & 200 & 100 \\
\hline
\end{tabular}

Source: Primary Data

From the table 8 , it is found that out of 200 sample respondents, the majority (144) of the sample respondents studied college level education, $18 \%$ of the sample respondents studied school level education and only $10 \%$ of the sample respondents are illiterates. Hence, it is concluded that the majority of the sample respondents studied college level education.

\section{Marital Status wise distribution of sample respondents}

The table. 9 shows the distribution of sample respondents on the basis of their marital status.

Table 9: Marital Status of Sample Respondents

\begin{tabular}{|l|c|c|}
\hline \multicolumn{1}{|c|}{ Marital Status } & No. of Respondents & Percentage \\
\hline Married & 24 & 12 \\
Unmarried & 176 & 88 \\
\hline Total & 200 & 100 \\
\hline
\end{tabular}

Source: Primary Data 
From the table 9, it is found that out of 200 sample respondents, the majority (176) of the sample respondents are married and $12 \%$ of the sample respondents are unmarried. Hence, it is concluded that the majority of the sample respondents are unmarried.

\section{Type of family wise distribution of sample respondents}

The table. 10 shows the distribution of sample respondents on the basis of their type of family.

Table 10: Type of family of Sample Respondents

\begin{tabular}{|l|c|c|}
\hline Type of Family & No. of Respondents & Percentage \\
\hline Joint & 84 & 42 \\
Nuclear & 116 & 58 \\
\hline Total & 200 & 100 \\
\hline
\end{tabular}

Source: Primary Data

From the table 10, it is found that out of 200 sample respondents, the majority (116) of the sample respondents belong to the Nuclear family and $42 \%$ of the sample respondents belong to the Joint family. Hence, it is concluded that the majority of the sample respondents belong to the Nuclear family.

\section{Monthly income of family wise distribution of sample respondents}

The table 11 shows the distribution of sample respondents on the basis of their monthly income of family. For analyzing this, sample respondents are grouped into four categories viz., Up to Rs.5000, Rs.5001-Rs.7500, Rs.7501-Rs. 10000 and Above Rs. 10000.

Table 11: Monthly Income of Family of Sample Respondents

\begin{tabular}{|l|c|c|}
\hline \multicolumn{1}{|c|}{ Monthly Income } & No. of Respondents & Percentage \\
\hline Up to Rs.5000 & 50 & 25 \\
Rs.5001 - Rs.7500 & 54 & 27 \\
Rs.7501 - Rs.10000 & 30 & 15 \\
Above Rs. 10000 & 66 & 33 \\
\hline Total & 200 & 100 \\
\hline
\end{tabular}

Source: Primary Data 
From the table.11, it is found that out of 200 sample respondents, the majority (66) of the sample respondents belong to the income group of 'Above Rs. 10000 per month'. Among 200 sample respondents, $25 \%$ of them belong to the income group of 'Up to Rs.5000 per month', $27 \%$ of them belong to the income group of 'Rs.5001 - Rs.7500' per month' and only $15 \%$ of them belong to the income group of 'Rs.7501 - Rs. 10000 per month'. Hence, it is concluded that the majority of the sample respondents belong to the income group of 'Above Rs. 10000 per month'.

\section{Monthly expenditure of family wise distribution of sample respondents}

The table 12 shows the distribution of sample respondents on the basis of their monthly expenditure of family. For analyzing this, sample respondents are grouped into four categories viz,, Up to Rs.3000, Rs.3001-Rs.5000, Rs.5001-Rs.7500 and Above Rs.7500.

Table 13 : Monthly Expenditure of Family of Sample Respondents

\begin{tabular}{|l|c|c|}
\hline \multicolumn{1}{|c|}{ Monthly Expenditure } & No. of Respondents & Percentage \\
\hline Up to Rs. 3000 & 56 & 28 \\
Rs.3001 - Rs. 5000 & 44 & 22 \\
Rs. 5001 - Rs. 7500 & 42 & 21 \\
Above Rs.7500 & 58 & 29 \\
\hline Total & 200 & 100 \\
\hline
\end{tabular}

Source: Primary Data

From the table 13, it is found that out of 200 sample respondents, the majority (58) of the sample respondents belong to the expenditure group of 'Above Rs.7500 per month'. Among 200 sample respondents, $28 \%$ of them belong to the expenditure group of 'Up to Rs.3000 per month', 22 $\%$ of them belong to the expenditure group of 'Rs.3001 - Rs.50000 per month' and only $21 \%$ of them belong to the expenditure group of 'Rs.5001 - Rs.7500 per month'. Hence, it is concluded that the majority of the sample respondents belong to the expenditure group of 'Above Rs.7500 per month'. 
Monthly expenditure of family for fairness cream wise distribution of sample respondents

The table 14 shows the distribution of sample respondents on the basis of their monthly expenditure of family for fairness cream. For analyzing this, sample respondents are grouped into four categories viz., Up to Rs.3000, Rs.3001-Rs.5000, Rs.5001-Rs.7500 and Above Rs.7500.

Table 14 : Monthly Expenditure of Family for Fairness Cream of Sample Respondents

\begin{tabular}{|l|c|c|}
\hline Monthly Expenditure & No. of Respondents & Percentage \\
\hline Up to Rs.50 & 82 & 41 \\
Rs. 51 - Rs.75 & 84 & 42 \\
Rs. 76-Rs. 100 & 16 & 8 \\
Above Rs. 100 & 18 & 9 \\
\hline Total & 200 & 100 \\
\hline
\end{tabular}

Source: Primary Data

From the table 14, it is found that out of 200 sample respondents, the majority (84) of the sample respondents belong to the expenditure group of 'Rs.51-Rs.75 per month for fairness cream'. Among 200 sample respondents, $41 \%$ of them belong to the expenditure group of 'Up to Rs.50 per month for fairness cream', $9 \%$ of them belong to the expenditure group of 'Above Rs. 100 per month for fairness cream' and only $8 \%$ of them belong to the expenditure group of 'Rs.76 - Rs. 100 per month for fairness cream'. Hence, it is concluded that the majority of the sample respondents belong to the expenditure group of 'Rs. 51 - Rs.75 per month for fairness cream'.

\section{Testing of Hypothesis: Chi-square Analysis (2)}

In the present study, the following null $(\mathrm{Ho})$ is framed:

Ho: There is no significant relationship between personal-economic factors and brand preference of fairness cream consumers

For testing the null hypothesis, chi-square test has been applied at $5 \%$ level of significance. The result of chi-square analysis is presented in the table 15. 
Table 15 : Relationship between Personal-Economic Factors and Brand Preference of Fairness Cream Consumers

\begin{tabular}{|l|r|r|r|r|}
\hline \multicolumn{1}{|c|}{$\begin{array}{c}\text { Personal - Economic } \\
\text { Factors }\end{array}$} & DF & $\begin{array}{r}\text { Calculated } \\
\text { Value }\left(\chi^{2}\right)\end{array}$ & $\begin{array}{r}\text { Table } \\
\text { Value }\end{array}$ & $\begin{array}{c}\text { Result @ 5 5evel } \\
\%\end{array}$ \\
\hline Age & 4 & 0.6629 & 9.488 & Insignificant \\
Gender & 4 & 7.1380 & 9.488 & Insignificant \\
Education & 8 & 10.3407 & 15.507 & Insignificant \\
Marital Status & 4 & 1.5730 & 9.488 & Insignificant \\
Type of family & 4 & 13.0885 & 9.488 & Significant \\
Monthly Income of Family & 12 & 6.8418 & 21.026 & Insignificant \\
Monthly Expenditure of Family & 12 & 11.5164 & 21.026 & Insignificant \\
Monthly Expenditure For & 12 & 4.0810 & 21.026 & Insignificant \\
Fairness Cream & & & &
\end{tabular}

Source: Primary Data

From the table 15, it is found that the calculated value of chi-square is less than the table value for all personal-economic factors except the type of family. Hence, the test is statistically insignificant and the null hypothesis is accepted for all personal-economic factors except type of family at $5 \%$ level of significance. In case of type of family, the test is significant and the null hypothesis is rejected.

Finally, it is concluded that there is no significant relationship between personal-economic factors and brand preference of fairness cream consumers and it is also concluded that there is significant relationship between the type of family and brand preference of fairness cream consumers.

\section{Problems Faced by the Fairness Cream Consumers}

Now a days, large number of fairness creams and different varieties are introduced in the market. As a result of this, customer finds it difficult to identify the quality products. Though the consumers are entitled to have certain basic rights, a considerable portion of consumers do not even aware of these rights. It encourages some manufacturers to do some 
malpractices which are against the interest of the customers. They do malpractices such as charging higher price, supplying sub-standard products, using false weights and measurements, deceptive advertisement etc. The fairness cream product consumers also facing the above said problems while using their brand. By considering this, in the present study, an attempt is made to analyze the problems faced by the fairness cream consumers. For analyzing this, nine problems are taken into consideration such as skin problem, high price, less quality, less quantity, problem in package, lack of freshness, lack of advertisement, adulteration and lack of offers \& discounts. For identifying the most significant problem faced by the fairness cream consumers among these factors, simple ranking technique has been applied. The table 16 reveals the ranking analysis of problems faced by the fairness cream consumers.

Table 16: Problems Faced by the Fairness Cream Consumers

\begin{tabular}{|l|c|c|c|}
\hline \multicolumn{1}{|c|}{ Problems } & Total Score & Mean Score & Rank \\
\hline Skin Problem & 1284 & 6.42 & 1 \\
High Price & 1220 & 6.10 & 2 \\
Less Quantity & 1192 & 5.96 & 3 \\
Problem in Package & 788 & 3.94 & 8 \\
Lack of Freshness & 926 & 4.63 & 5 \\
Less Quality & 892 & 4.46 & 6 \\
Adulteration & 740 & 3.70 & 9 \\
Lack of Advertisement & 1094 & 5.47 & 4 \\
Lack of Offers \& Discounts & 864 & 4.32 & 7 \\
\hline
\end{tabular}

Source: Primary Data

The table 5 shows that among the nine problems taken into consideration, Skin Problem is ranked as first problem with total score of 1284. High Price (1220), Less Quantity (1 192), Lack of Advertisements (1094) and Lack of freshness (926) are ranked as second, third, fourth and fifth problems respectively and other problems followed them. Hence, it is concluded that the skin problem is the most significant problem faced by the fairness cream consumers. 


\section{Findings of the Study}

- In this study, it is found that the majority of the fairness cream consumers prefer 'Fair \& Lovely' brand fairness cream.

- In this study, it is found that the majority of the fairness cream consumers prefer 100 Grams quantity of fairness cream.

- In this study, it is found that the majority of the sample respondents got information about a particular brand of fairness cream through 'advertisements'.

- In this study, it is found that the majority of sample respondents purchased their brand of fairness cream from 'medical shops'.

- In this study, it is found that the quality is the most significant factor, which influences the brand preference of fairness cream consumers.

- In this study, it is found that there is no significant relationship between personal-economic factors and brand preference of fairness cream consumers and it is also found that there is significant relationship between the type of family and brand preference of fairness cream consumers.

- In this study, it is found that the skin problem is the most significant problem faced by the fairness cream consumers.

\section{Conclusion}

In this study, it is found that the Skin problem is the most significant problem faced by the fairness cream consumers. During the field study, it is observed that most of the fairness cream consumers felt that sometimes applying fairness cream creates pimples and skin allergy. Hence, it is suggested that the producers of fairness cream may consider this and may take some measures to overcome above said problem. If they will do so, consumers satisfaction may be improved and they can capture more market share their brands. 


\section{Bibliography}

Gupta S.P., "Statistical Methods", Sultan Chand \& Sons, New Delhi, 1984.

Kothari C.R., "Research Methodology", New Age International (P) Ltd., 2004.

Suja R. Nair, "Consumer Behaviour and Marketing Research", Himalaya Publishing House, New Delhi, 2004. 